\title{
Environmental Financial Performance Evaluation of Manufacturing Enterprises in Shanghai*
}

\author{
Wei Sun \\ Collaborative Innovation Center on Forecast and \\ Evaluation of Meteorological Disasters, \\ School of Economics and Management, \\ Nanjing University of \\ Information Science \&Technology, Nanjing, China \\ ${ }^{\dagger}$ E-mail: sunwei16@nuist.edu.cn \\ Xiang $\mathrm{Yu}$ and Arinaitwe Micheal \\ School of Economics and Management, \\ Nanjing University of Information Science \&Technology, \\ Nanjing, China
}

\begin{abstract}
The uncertain global economic environment since 2008 has complicated life for manufacturers everywhere including China. The purpose of this article is to identify major challenges facing the Chinese manufacturing industry. We used entropy weight method to analyze the financial information from 60 Chinese manufacturing companies' reports and developed an evaluation system for evaluating the performance of the firms. Then, we determined the entropy of each evaluation indicator after which the weights were computed accordingly. The proposed method was also used in determining the ranking of the firms using a composite score ranking system by comparing the firms according to the criteria determined. Overall from the composite score ranking Shanghai Wallace, Shanghai Ganglian E-Commerce, Bairun Gufe remained at the forefront of environmental financial performance with the highest performance score while the environmental financial performance score of Shanghai Automation Instrumentation, Daying Modern Agriculture and Jielong Industry was basically low, living them at the bottom.
\end{abstract}

Keywords: Environmental financial performance; Manufacturing; Entropy weight method; China.

\section{Introduction}

Manufacturing industry refers to those industries which involve in the manufacturing and processing of items and indulge in either creation of new

\footnotetext{
*This work is supported by universities' philosophy and social science research project in Jiangsu Province (2016SJB630018) and Social Science Applied Research Quality Engineering in Jiangsu Province (16SYB-002).
} 
commodities or in value addition for example agricultural and sideline products processing, food, drink and tea beverages, tobacco, textiles, wood processing, printing, petroleum, chemical processing, pharmaceutical, metal products, General equipment manufacturing, equipment among others.

Manufacturing, as its name suggests, is the use of available resources for production to meet the demand of the market. The ending products can either function as a finished good for sale to consumers or as intermediate goods used to continue the production process. Therefore, the manufacturing sector is to a large extent dependent on the market demand, changes in market demand determines the direction and future of manufacturing. Manufacturing industry in China is of great interest to those countries and companies trading or competing with China in manufactured products. Manufacturing industries came into being with the occurrence of technological and socio-economic transformations in the Western countries in the 18th-19th century. This was widely known as industrial revolution. It began in Britain and replaced the labor intensive textile production with use of machines and use of fuels.

The manufacturing industry accounts for a significant share of the industrial sector in china. According to the 2013 Global Manufacturing Competitiveness Index Manufacturing by DTTL (2013) Manufacturing GDP percentage of total GDP 2010 was $32.4 \%$. EW world economy team (2013) puts the figure even higher at 45.3 percent of China's GDP. In 2012, China overtook the United States as the world's largest merchandise trading economy exports plus imports which are largely driven by the manufacturing industry (Morrison, 2015).

China is a powerhouse in global manufacturing, as China has become a major manufacturing power, producing about $90 \%$ of manufactured goods globally ( $\mathrm{Li}, 2013)$. The global economic crisis that began in 2008 greatly affected China's economy exports largely products from the manufacturing industry, Real GDP fell from $10.4 \%$ in 2010 to $7.8 \%$ in 2012, to $7.4 \%$ in 2014 . The IMF projects that China's real GDP growth will slow to $6.8 \%$ in 2015 and to $6.1 \%$ in 2016. (Morrison, 2015). Amid all this by 2010, China had surpassed Japan as the second largest economy in the world based on a purchasing power parity basis.

In order to get a deeper understanding all this, this research Selected 60 manufacturing companies listed on the Shanghai Stock Exchange, looked at their environmental financial performance indicators, analyzed them, in order to explore the influence behind the environmental financial performance.

\section{Data source and Process}

After taking into account the characteristics of manufacturing companies listed Shanghai stock exchange, this paper selected a total of 5 types level 1 indicators 
and 9 level 2 indicators to construct the index system as table 1.. The index system has two levels. The first level index is primary factor layer and each evaluation index in the first level includes several secondary factors, which is called the second level index that make the whole Evaluation index.

Table 1 Construction of Financial Performance Index System variables of Shanghai manufacturing enterprises

\begin{tabular}{|c|c|c|}
\hline Level one indicators & level Two index & level Three index \\
\hline \multirow{9}{*}{$\begin{array}{c}\mathrm{U} \\
\text { Financial Performance } \\
\text { Indicators }\end{array}$} & $\begin{array}{c}\mathrm{U} 1 \\
\text { Capital Structure }\end{array}$ & U11 Asset-liability ratio \\
\hline & \multirow[t]{2}{*}{ U2Operating capacity } & U21 Inventory turnover \\
\hline & & $\begin{array}{c}\text { U22 } \\
\text { Total assets turnover }\end{array}$ \\
\hline & \multirow{2}{*}{ U3Profitability } & $\begin{array}{c}\text { U31 } \\
\text { Return on Equity (ROE) }\end{array}$ \\
\hline & & $\begin{array}{c}\text { U32 } \\
\text { Return on Assets (ROA) }\end{array}$ \\
\hline & \multirow{2}{*}{$\begin{array}{c}\mathrm{U} 4 \\
\text { Growth ability }\end{array}$} & $\begin{array}{c}\text { U41 } \\
\text { Total Assets } \\
\text { year-to-year growth }\end{array}$ \\
\hline & & $\begin{array}{c}\text { U42 } \\
\text { Net Profit year-to-year growth }\end{array}$ \\
\hline & \multirow{2}{*}{ U5Solvency } & $\begin{array}{c}\text { U51 } \\
\text { Current Ratio }\end{array}$ \\
\hline & & $\begin{array}{c}\mathrm{U} 52 \\
\text { Equity ratio }\end{array}$ \\
\hline
\end{tabular}

According to the characteristics of manufacturing enterprises, this paper chooses Entropy weight method as the method of analyzing financial performance since it can effectively avoid the interference of subjective factors in the process of evaluation. Entropy weight method is used to calculate the entropy weight according to the degree of variation of each index, so as to get the objective index weight. The key steps of the entropy weight method used include: formation of the original matrix from the raw data, which is then standardized to form an evaluation matrix such that the data fits within unity (1) i.e. all data values will take on a value of 0 to 1 . Then calculation of the entropy and the entropy weight of each indicator and finally get a comprehensive evaluation score for each observation.

\section{Results and Discussion}

In this paper, financial data of 60 sampled manufacturing enterprises on the Shanghai Stock Exchange market in China were ranked from the analyzed data 
to get the results. In the entropy weight method used, the greater the value of the entropy, the smaller the entropy weight and on the other hand, the smaller the entropy the greater is the weight hence a larger weight would mean the indicator provides more useful information. The lesser the information an indicator gives, the less important it becomes in a given decision making process and vice versa. Since entropy is used as a measurement for uncertainty, the more the information, the less the uncertainty. Therefore, the information provided by Inventory turnover rate, total asset turnover, Total assets, current ratio, indicators is relatively greater than the rest of the indicators used in the study implying that these four indicators have a great influence on the environmental financial performance evaluation of the enterprises in this study.

The top-ranking companies scored relatively high with most of the indicators used in the evaluation process reflecting business development and short-term solvency. It can be seen that the environmental financial performance composite score ranking of the listed manufacturing enterprises was largely influenced by the operational capacity indicator with the largest weight. Operating capacity can be regarded as one of the best ways of evaluating the environmental financial performance of the enterprises in this study. The results of the operational capacity's two sub-indices Inventory turnover rate and Total assets turnover rate were relatively high hence impacting the evaluation of the environmental financial performance the enterprises. On the other hand, the Capital structure indicator has the least weight providing little information on the score, which means that it has little effect on the environmental financial performance evaluation in this study.

From the analyzed results above the following can be deducted from the environmental financial performance of these 60 evaluated manufacturing enterprises:

Shanghai Wallace, Huaping Gufen, Bairun Gufe ranked highest in terms of Capital structure. Shanghai Ganglian E-Commerce, Long Yu fuel, Shanghai Sanmao ranked highest in terms of operating capacity. Morning Glory, Shanghai Jahwa, alkali chemical industry ranked highest in terms of Profitability. Shanghai Wallace, CSG Smart Science \& Technology, Fly Cam Materials ranked highest in terms of Growth ability Bairun Gufe, Huaping Gufen, Shanghai Kai Bao ranked highest in terms of Solvency.

Overall from the composite score ranking Shanghai Wallace, Shanghai Ganglian E-Commerce, Bairun Gufe remained at the forefront of environmental financial performance with the highest performance score while the environmental financial performance score of Shanghai Automation Instrumentation, Daying Modern Agriculture and Jielong Industry was basically low, living them at the bottom. 
The environmental financial performance of the evaluated manufacturing enterprises was most affected by the operation capacity especially the inventory turnover rate and the total asset growth, the second was growth ability, thirdly solvency, fourth profitability and capital structure had the least effect on the environmental financial performance evaluation. However, in the study many enterprises with strong operational capability and high growth ability still had a very low comprehensive score after ranking, which shows that although the two had a great impact on environmental financial performance evaluation, the environmental financial performance is a comprehensive evaluation of all results not just a single indicator. Therefore, the need for comprehensive analysis of all indicators.

\section{References}

1. Deloitte Touche Tohmatsu Limited (DTTL) Global Manufacturing Industry group. (2013). Global Manufacturing Competitiveness Index. www.deloitte.com/manufacturing.

2. EW world economy team. (2013, JUNE 4). Economic Structure of China. Economywatch.com,http://www.economywatch.com/world_economy/china /structure-of-economy.html

3. Jia, Z., Fan, Z., Chen, S. (2011). Fuzzy Comprehensive Evaluation of Peak Load Unit Based on Entropy Weight. Intelligent Computing and Information Science 134: 737-743

4. Li, L. (2013). The path to Made-in-China: How this was done and future prospects. International Journal Production Economics, 146; 4-13.

5. Li, Y., Wei, Z., Zhao, J., Zhang, C., Liu, Y. (2012). Ambidextrous organizational learning, environmental munificence and new product performance: Moderating effect of managerial ties in China. Int. J. Production Economics, 146; 95-105.

6. Morrison, W, M. (2015). China's Economic Rise: History, Trends, Challenges, and Implications for the United States. Congressional Research Service. www.crs.gov.

7. Zhou, H and Li, L. (2013). Manufacturing practices in China. International Journal Production Economics, 146:1-3.

8. Zhou, R., Cai, R., Tong, G. (2013). Applications of Entropy in Finance: A Review. Entropy 15: 4909-4931.

9. Banister, J. (2013). China's manufacturing employment and hourly labor compensation, 2002-2009. International Labor Comparisons. www.bls.gov/ilc.

10. BP Statistical Review of World Energy, UK. (2014). BP Statistical Review of World Energy June 2014. London: Printing Pureprint Group Limited. 
11. Cui, W. J, Cui, X. H, Hao, C. (2009). Study of Manufacturing Competitiveness in Jiangsu, China from a New Pattern Perspective. IEEE International Conference on Grey Systems and Intelligent Services. November 10-12, 2009, Nanjing, China.

12. Jiang. S. (2010). Coping with the International Financial Crisis: Europe and China Compared, Working Paper Series on European Studies, Institute of European Studies, Chinese Academy of Social Sciences. Vol. 4, No. 1, 2010.

13. Lai, K., Wu, S., Wong, C. (2013). Did reverse logistics practice shit the triple bottom line of Chinese manufacturers? International Journal of Production Economics, 146; 106-117.

14. McFarlan, F. W. (2008). China: Opportunity and Challenge. Harvard Business School the Centennial Global Business Summit, Summit Report 2008.

15. Wang, X, H., Zheng, J., PU, T, J., XU, H, L. (2014) study on smart grid assessment basses of fuzzy evaluation. International Conference on Energy and Power Engineering (EPE2014). Hong Kong, China.

16. McCormack. R. (2015). Chinese Workers Have A Very Long Way To Catch Up To American Manufacturing Wages. http://itac.nyc/chineseworkers-have-a-very-long-way-to-catch-up-to-american-manufacturingwages/. Accessed on 2015/12/30.

17. Zhi-hong, Z., Yi, Y., Jing-nan, S. (2006). Entropy method for determination of weight of evaluating in fuzzy synthetic evaluation for water quality assessment indicators. Journal of environmental sciences 18: 1020-1023.

18. Zhengyuan, J., Chunmei, W., Zhiwei, H., Gang, Z. (2011). Evaluation Research of Regional Power Grid Companies' Operation Capacity based on Entropy Weight Fuzzy Comprehensive Model. Procedia Engineering 15; $4626-4630$.

19. Yang, M., Patino-Echeverri, D., Yang, F., Williams, E. (2014). Industrial energy efficiency in China: Achievements, challenges and opportunities. Energy Strategy Reviews, 6; 20-29. 